\title{
Psykoser og kriminalitet i Norge
}

\author{
Av professor, dr. med. L. EITINGER, Oslo
}

\section{Innledning}

Blant legfolk er det en meget utbredt oppfatning at alvorlige sinnslidende personer som regel er særdeles farlige og begår svært mange ukontrollerte kriminelle handlinger, særlig voldsforbrytelser. Den foreliggende litteratur er ikke entydig i sine slutninger. Rappeport og medarbeidere (8) skriver i A review of the literature on the dangerousness of the mentally ill $f \phi 1$ gende: „Crime rates are not higher among ex-mental patients than among corresponding persons in the general population; indications are that the reverse is true." De vesttyske forfattere Häfner og Böker $(1,6)$ er av den samme oppfatning, og anser som den vesentligste konklusjon av sine omfattende rettspsykiatriske unders $\varnothing$ kelser at voldskriminaliteten begått av sinnssyke og oligofrene kvantitativt svarer til den som begåes av den gjennomsnittlige totalpopulasjon. I motsetning til disse forfattere fant Giovannoni \& Gurel (2) at de schizofrene ex-pasienter de hadde unders $\varnothing \mathrm{kt}$ hadde relativt hyppigere arrestasjoner for homicid, rov og overfall. Deres tall er dog forholdsvis små. Også Zitrin et al. (10) kom til liknende resultater, men også disse på grunnlag av svært små tall. Lagos et al. (7) fant at hele $36 \%$ av 321 innlagte psykiatriske pasienter hadde en voldsom eller fryktskapende atferd $\mathrm{f} \phi \mathrm{r}$ innleggelsen. Forfatterne mener derfor at man ikke burde avfeie publikums angst for psykotiske personers atferd som irrasjonell. Guzes (4) store unders $\phi$ kelse viser en klar forskjell mellom de psykiatriske abnormtilstander man finner hos en fengselspopulasjon og dem som kan diagnostiseres i psykiatriske sykehus, med forholdsvis beskjeden overlapping. De „vanlige“ psykoser finnes etter Guze ikke hyppigere hos lovovertredere enn hos den gjennomsnittlige befolkning. Gunn (3) er i sin oversikt fra Storbritania noe mere tilbakeholdende, og mener at det er vanskelig å finne klare relasjoner mellom lovovertredelse og mentale forstyrrelser. For det første er begge begrep meget heterogene, ikke entydige, og sterkt kulturavhengige. Dette gjelder ikke minst lovovertredelser. Han fremholder at alle pålitelige unders $\varnothing$ kelser viser at lovovertredelser er i det hele tatt meget hyppige, og at de derfor må forventes å forekomme også blant psykiatriske pasienter. Nøyaktige unders $\phi$ kelser av populasjoner $\mathbf{i}$ fangesituasjoner vil på den andre siden vise at de omfatter tallrike psykiatriske tilfeller, om enn ikke alltid psykotikere. Dette henger helst sammen med institusjonenes funksjon, og kan på ingen måte brukes som bevis på at det foreligger en korrelasjon mellom forbrytelser og sinnslidelse. 
Selv om det er meget som taler for Gunns mere differensierte og kritiske syn, kan det være av interesse å se på situasjonen i Norge, hvor spørsmålet om sammenheng mellom psykoser og kriminalitet ikke har vært unders $\varnothing$ kt tidligere. Den foreliggende undersøkelse som tar opp dette spørsmål, vil derfor kanskje kunne påregne noen interesse.

\section{Norsk lovgivning}

Straffelovens $\S 44$ bestemmer at en handling ikke er straffbar dersom gjerningsmannen har vært sinnssyk på den tid da han begikk den straffbare handling. $\S 39$ bestemmer bl. a. at en sinnssyk som har begått en straffbar handling og hvor der er fare for gjentagelse av tilsvarende handlinger p.g.a. sinnssykdom kan/b $\phi \mathbf{r}^{\mathrm{r}}$ sikres. Foreligger det ikke fare for gjentagelse, må saken henlegges.

For å få bragt på det rene om der foreligger fare for gjentagelse, må den mistenkte undergis judisiell observasjon. Dette skjer av praktiske grunner imidlertid i bare relativt få tilfeller, mindre alvorlige lovovertredelser begått av opplagt psykotiske personer blir henlagt uten at saken reises ved noen domstol. Gjerningsmannen blir som regel innlagt ad administrativ vei i et psykiatrisk sykehus på samme måte som andre, ,ikke-kriminelle" psykotiske pasienter.

\section{Materiale og metode}

For å skaffe seg en total oversikt over alle psykotiske pasienter som hadde vært i konflikt med straffeloven, måtte derfor både de judisielt observerte og de ,henlagte“ saker granskes. For å få et representativt materiale valgte man å unders $\phi$ ke tre fortl $\varnothing$ pende år, og for å få en tilstrekkelig lang observasjonstid ble årene 1965/66/67 valgt. Jeg gjennomgikk derfor alle rettspsykiatriske erklæringer fra disse 3 år, og fant frem til alle de hvor de sakkyndige hadde konkludert med at siktede hadde vært sinnssyk på gjerningstiden. De tallmessige forhold for de judisielle observasjoner fremgår av tabell 1.

Tabellen viser at bare et fåtall (ca. $5 \%$ ) av de observerte blir funnet å ha vært sinnssyke på gjerningstiden. Det er påfallende flere (prosentmessig) kvinner i denne gruppen. Dette henger sammen med den generelt lavere kriminalitet blant kvinner. Relativt flere kvinner vil begå straffbare handlinger som blir antatt å stå i kausal sammenheng med den abnorme sinnstilstanden.

Etter å ha innhentet Justisdepartementets samtykke til undersøkelsen, henvendte jeg meg til Statistisk Sentralbyrå med anmodning om å få en oversikt over alle siktede personer som har 
PSYKOSER OG KRIMINALITET I NORGE

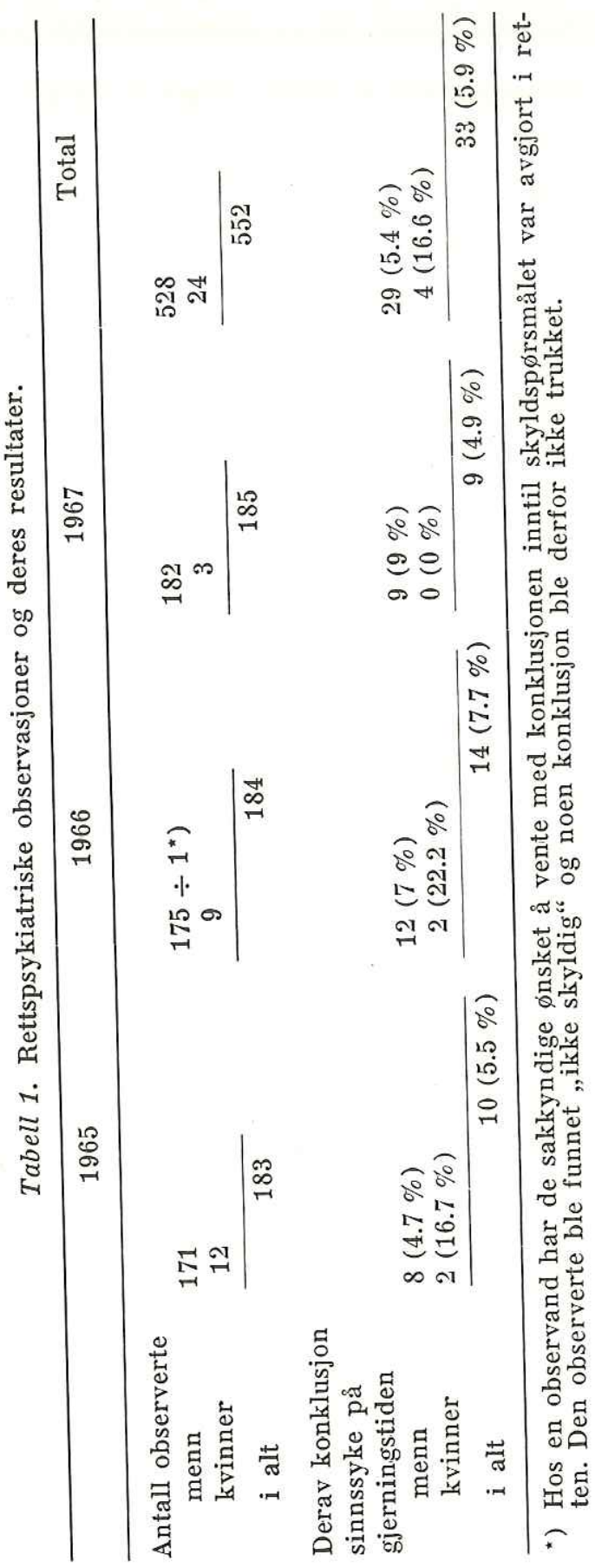


fått sin sak henlagt p.g.a. bevisstl $\phi$ shet/sinnssykdom på gjerningstiden i løpet av de ovennevnte 3 år.

Det er politimesteren i hvert politidistrikt som avgjør hvorvidt en sak skal følges videre eller henlegges. Fra Statistisk Sentralbyrå fikk jeg navnene på 265 personer hvis sak var blitt henlagt i l $\phi$ pet av de nevnte 3 år, fordelt på landets 50 politikamre, med fra 1 til 50 tilfeller. Justisdepartementet hadde også gitt sitt samtyke til å innhente aktene fra politikamrene, og dette ble gjort. Som man måtte vente, var ikke alle akter uten videre tilgjengelige. Til tross for stor im $\phi$ tekommenhet og intense anstrengelser, var det ikke mulig å finne aktene for 22 personer. Det viste seg videre at 25 tilfeller var blitt henlagt fordi den mistenkte var blitt ansett som psykisk utviklingshemmet i så $\mathrm{h} \phi \mathrm{y}$ grad at politiet fant en videre forf $\phi$ lgelse av saken meningsløs. (Denne avgjørelse var som oftest bygget mere på erfaringene og skjønnet til politiembetsmennene enn på en psykologisk eller medisinsk psykiatrisk unders $\emptyset$ kelse.) Også disse 25 måtte sjaltes ut da de ikke h $\phi$ rte til det egentlige materiale av sinnssyke.

Videre var ytterligere 68 saker man hadde fått utlånt, blitt henlagt av andre grunner enn sinnssykdom. Detaljene fremgår av tabell 2 .

Tabell 2. Oversikt over materialets sammensetning.

Henlagte saker, meddelt fra Statistisk Sentralbyrå

Derav sjaltet ut fordi:

Aktene kunne ikke finnes

Henlagt fordi mistenkte ble ansett som åndssvak

Mistenkte $d \varnothing d$ under etterforskningen

Saken foreldet $\mathbf{f} \phi \mathbf{r}$ etterforskningen ble satt $\mathrm{i}$ gang

Mistenkte under kriminell lavalder

Saken feilkodet

Saken „dobbelført“ (judisielt observert)

I materialet meddelt fra Statistisk Sentralbyrå

I materialet meddelt fra $\mathrm{DRMK}^{\star}$ )

Totalmateriale

*) Den Rettsmedisinske Kommisjon.
22

25

6

5

8

49

$\begin{array}{r}419 \\ \hline 146\end{array}$

33

179

Ytterligere 4 saker måtte sjaltes ut fordi vedkommende var blitt unders $\varnothing \mathrm{kt}$ judisielt, og disse 4 tilfellene er tatt med under de 33 fra Den rettsmedisinske kommisjon. Totalmaterialet består således av 146 tilfeller av lovovertredelser som er blitt henlagt av politimesteren, pluss 33 pasienter som er blitt judisielt 
observert, og hvis papirer man har fått utlånt fra Den rettsmedisinske kommisjon. Tilsammen er det 179 unders $\varnothing$ kte tilfeller.

Det vil være vanskelig å trekke noen kvantitative slutninger av det foreliggende tallmaterialet. I bare 81 tilfeller (eller $45.3 \%$ ) dreide det seg om f $\phi$ rstegangsinnleggelser. Antallet f $\varnothing$ rstegangsinnlagte i norske psykiatriske sykehus i årene 1965/66/67 var 8148 pasienter. Våre 81 unders $\phi$ kte f $\phi$ rstegangsinnlagte, utgj $\phi r$ således ikke mer enn $0.9 \%$. Sammenlignet med totalbefolkningens registrerte kriminalitet ville disse tall st $\phi$ tte den oppfatning at lovovertredelser blant f $\varnothing$ rstegangsinnlagte psykotiske pasien-

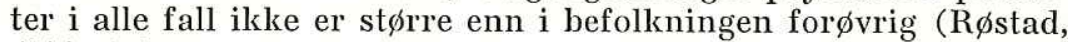
(9)). Disse tall bør imidlertid ikke tillegges altfor stor betydning. For det første er de små, og en del saker er som ovenfor nevnt ikke blitt funnet. Tallene sier videre ikke noe om en eventuell senere kriminalitet hos personer som allerede er psykotiske. Hos $1 / 3$ av våre pasienter $(33.6 \%$ ) gjaldt det gjeninnleggelser, og resten, d.v.s. ca. $10 \%$ var under institusjonell psykiatrisk behandling da de begikk straffbare handlinger. Våre 179 pasienter utgj $\phi \mathbf{r}$ ca. $1.1 \%$ av de ca. 15500 psykiatriske pasienter som i løpet av ett år befinner seg innenfor den psykiatriske omsorg $\mathrm{i}$ Norge, d.v.s. psykiatriske sykehus (ca. 8400 ), psykiatriske sykehjem (ca. 4 400) og familiepleie (ca. 2700 ). Den norske politistatistikk viser at det i 1966 (året mellom 1965 og -67) ble etterforsket 48630 forbrytelser eller $1.3 \%$ pr. innbygger. Med alle

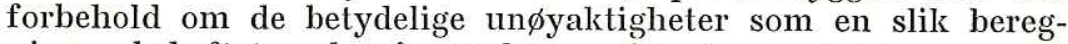
ning er beheftet med, må man kunne si at de psykiatriske pasienter ikke ligger dårligere an enn gjennomsnittsbefolkningen.

Alle tilgjengelige opplysninger fra politietterforskningene og fra de rettspsykiatriske erklæringer vedr $\phi$ rende de 179 personer ble overf $\phi$ rt til et kodeskjema. Takket være Sentralregisteret ved Gaustad sykehus var det mulig å få slått fast om og på hvilke psykiatriske sykehus de registrerte hadde vært innlagt, og alle journaler (eventuelt journalkopier) ble velvilligst utlånt fra sykehusene. Opplysningene fra journalene ble også overf $\phi r t$ til kodeskjemaene. Det viste seg at noen av pasientene også hadde vært observert judisielt enten f $\varnothing \mathbf{r}$ eller etter den unders $\varnothing$ kte treårsperioden, og de supplerende rettspsykiatriske erklæringer ble utlånt.

For å få et bilde av de unders $\varnothing$ ktes kriminelle 1 $\phi$ pebane, ble Strafferegisteret gjennomgått og alle bøter og straffer kodet. Dette gjaldt forgåelser både før, under og etter den egentlige observasjonsperioden 1965/66/67. Dette var delvis allerede en del av etterundersøkelsen som ble foretatt i det vesentlige på grunnlag av sykehusenes journalopptegnelser. I Statistisk Sentralbyrå ble det dessuten funnet alle de som var døde i observasjonsperioden, d.v.s. 1965-1975. 
Materialets kjønns- og aldersfordeling fremgår av tabell 3.

Tabell 3. Totalmaterialets alders- og kjønnsfordeling (i \%).

\begin{tabular}{|c|c|c|c|c|c|c|c|c|c|}
\hline & \multicolumn{3}{|c|}{ Menn } & \multicolumn{3}{|c|}{ Kvinner } & \multicolumn{3}{|c|}{ I alt } \\
\hline & $\mathrm{N}=156$ & $\%$ & & $\mathrm{~N}=23$ & $\%$ & & $\mathrm{~N}=179$ & $\%$ & \\
\hline -19 år & & 10.9 & & & 8.7 & & & 10.6 & \\
\hline $20-24$ år & & 12.8 & & & 8.71 & & & $12.3 \mid$ & \\
\hline $25-29$ år & & 12.2 & 25.0 & & $4.2\}$ & 13.0 & & $11.2\}$ & 23.5 \\
\hline $30-39$ år & & 19.2 & & & $8.7^{\prime}$ & & & $17.9^{\prime}$ & \\
\hline $40-49$ år & & 23.7 & & & 26.1 & & & 24.0 & \\
\hline $50-59$ år & & 12.8 & & & 26.1 & & & 14.5 & \\
\hline $60-69$ år & & 3.8 & & & 17.4 & & & 5.6 & \\
\hline 70 - år & & 4.5 & & & - & & & 3.9 & \\
\hline Sum & & 100.0 & & & 100.0 & & & 100.0 & \\
\hline
\end{tabular}

\section{Pasientenes sosiale bakgrunn}

Nesten $90 \%$ av de unders $\phi$ kte (156) var f $\varnothing \mathrm{dt}$ i ekteskap, 10 personer utenfor, hos 5 var faren ukjent og hos 8 fantes det ingen sikre opplysninger om dette forhold. Nesten halvparten $(48.6 \%)$ av alle unders $\phi$ kte var vokst opp under sosialt ikke tilfredsstillende forhold, og hele $52 \%$ anga at deres barndomshjem ikke hadde vært harmonisk. I hele $58 \%$ av tilfellene (92 menn og 12 kvinner) er det anf $\emptyset$ rt at det er andre kjente tilfeller av sinnslidelser i slekten, men bare i $5 \%$ er det berettet om både sinnslidelser og kriminalitet i familien.

Beskrivelsen av den premorbide personlighet som man finner den i psykiatriske journaler eller rettspsykiatriske observasjoner, vil alltid være problematisk. Ikke bare hukommelsesforskyvninger, men også påvirkning av den aktuelle situasjon (psykotisk lovovertreder!) ved journalopptaket vil spille en rolle. Det er derfor kanskje ikke noen grunn til å feste seg særlig ved den kjensgjerning at bare ca. $15 \%$ er beskrevet som premorbid upåfallende personlighet, mens vel $30 \%$ er betegnet som premorbid enten aggressiv, pågående eller svært mistenksom til det subparanoide. Vel like mange er beskrevet som meget tilbakeholdende, selvusikker, uselvstendig, isolert, mens resten har fått andre karakteristika eller er uten opplysninger om den premorbide personlighet.

Hos ca. $10 \%$ foreligger det beretning om (betydelige) hodeskader i barndommen. Ytterligere $5 \%$ hadde hatt andre organiske hjernesykdommer som har påvirket deres utvikling. Like mange hadde dessuten hatt generelle somatiske sykdommer som 
har ført til ett handikap. Vel $20 \%$ av de unders $\phi$ kte startet således sin løpebane med tydelige somatogene mangler som nok reduserte deres muligheter for senere tilpasning.

Utdannelsesmessig ligger de unders $\phi$ kte i det foreliggende materiale langt under landets gjennomsnitt. Over $10 \%$ hadde mindre enn 7 års skoleutdannelse p.g.a. lav intelligensmessig utvikling, og vel halvparten av alle unders $\varnothing$ kte hadde bare 7 års grunnutdannelse uten videre teoretisk eller praktisk tilleggsutdannelse. Bare 8, eller $4.5 \%$ av de unders $\varnothing$ kte hadde artium, og $3(1.7 \%)$ h $\phi y$ skoleutdannelse. Hos over $20 \%$ var det (enten p.g.a. utf $\varnothing$ rlige psykologiske tests eller i noen tilfelle bare p.g.a. klinisk inntrykk) konstatert at den intellektuelle utvikling mătte anses som liggende under det normale. Bare $17 \%$ var faglærte arbeidere, men dette tallet var nesten halvert når det gjaldt den beskjeftigelse de unders $\phi$ kte hadde på tiden da de begikk den straffbare handling. Det var således en tydelig reduksjon i yrkessituasjonen allerede f $\phi \mathrm{r}$ vedkommendes kriminalitet og sinnslidelse var blitt manifeste.

Alt i alt viser både de undersøktes bakgrunn, utdannelse og yrkesfordeling en saerdeles underpriviligert gruppe av befolkningen. Dette inntrykket bestyrkes videre av den kjensgjerning at bare $20 \%$ hadde klart et stabilt arbeidsliv, mens over $1 / 3$ var meget skiftende og påfallende ustabile.

Bare $25 \%$ av de unders $\varnothing$ kte menn hadde avsluttet sin militærtjeneste, hele $39.7 \%$ er blitt kjent udyktige allerede ved sesjonen og ytterligere $5 \%$ under tjenesten. Resten hadde fått utsatt sin tjeneste, men ikke påbegynt den igjen eller de hadde av andre grunner ikke vært $\mathrm{i}$ stand til å avslutte den på vanlig måte.

Også når det gjelder forholdet til det annet kjønn viser våre unders $\phi$ kte en noe uvanlig sammensetning, idet hele $24 \%$ aldri har hatt fast følge (og over $20 \%$ aldri har hatt heteroseksuelle kontakter). Detaljer fremgår av tabell 4 .

Som det kunne ventes, har alkohol spilt en viss rolle for det aktuelle klientel, dog har hele $10 \%$ erklært å ha vært avholdende gjennom hele livet, og nesten $40 \%$ å ha brukt alkohol „moderat“ eller „bare til selskapsbruk“. Nesten $45 \%$ var misbrukere fra lettere til meget alvorlige former. Derimot har bruk, henholdsvis misbruk av narkotika spilt bare en helt ubetydelig rolle i dette materiale (ca. $4 \%$ overforbruk eller misbruk). Dette må imidlertid sees på som rent tidsbetinget på grumn av narkotikamisbrukets ubetydelige utbredning på den tiden undersøkelsen gjelder.

De unders $\varnothing$ ktes sosiale situasjon på tiden for lovovertredelsen var også forholdsvis mangelfull og lite tilfredsstillende. Bare $1 / 4$ levde i ekteskap, som dog i kun $13 \%$ lkunne betegnes som vellykket. En tredjedel var mer eller mindre avhengige av andre 
Tabell 4. Forhold til det annet kjønn (i \%).

\begin{tabular}{|c|c|c|c|c|c|c|}
\hline & \multicolumn{2}{|c|}{ Menn } & \multicolumn{2}{|c|}{ Kvinner } & \multicolumn{2}{|c|}{ I alt } \\
\hline & $\mathrm{N}=156$ & $\%$ & $\mathrm{~N}=23$ & $\%$ & $\mathrm{~N}=179$ & $\%$ \\
\hline Aldri heteroseksuell kontakt & & 21.8 & & 13.0 & & 20.7 \\
\hline $\begin{array}{l}\text { Bare tilfeldige kontakter og } \\
\text { promiskuitet }\end{array}$ & & 9.6 & & 17.4 & & 10.6 \\
\hline $\begin{array}{l}\text { „Normale“ heteroseksuelle } \\
\text { kontakter }\end{array}$ & & 49.4 & & 56.5 & & 50.3 \\
\hline Andre og usikre opplysninger & & 19.2 & & 13.0 & & 18.5 \\
\hline Aldri „fast f $\varnothing$ lge“ & & 24.4 & & 21.7 & & 24.0 \\
\hline Ugift/forlovet & & 38.5 & & 30.4 & & 37.4 \\
\hline Gift/flere gg. gift & & 23.1 & & 47.8 & & 26.3 \\
\hline Skilt, ikke gjengift & & 12.8 & & - & & 11.2 \\
\hline Ikke sikre opplysninger & & 1.3 & & 一 & & 1.1 \\
\hline Ingen barn & & 65.4 & & 69.6 & & 65.9 \\
\hline Barn født i ekteskap & & 28.8 & & 26.1 & & 28.5 \\
\hline Barn f $\emptyset \mathrm{dt}$ utenfor ekteskap & & 2.5 & & - & & 2.3 \\
\hline Ikke sikre opplysninger & & 3.2 & & 4.3 & & 3.4 \\
\hline
\end{tabular}

familiemedlemmer, for det meste foreldre eller s $\varnothing$ sken, mens hele $26 \%$ levde alene og isolert, og bare $5 \%$ av disse hadde det man kan kalle et sosialt noenlunde sikret utkomme. De andres kår var temmelig elendige.

De psykiatriske funn

Pasientenes psykiatriske avvik ble f $\varnothing$ rst bed $\varnothing \mathrm{mt}$ etter symptomatologien og deretter diagnostisk. Det paranoide/paranoiske symptom var det mest fremtredende. Trefjerdedeler av alle unders $\phi$ kte hadde vrangforestillinger, de fleste forf $\phi$ lgelsesforestillinger, mens resten fordelte seg på sjalusiparanoiske, religi $\phi$ se og erotiske vrangforestillinger. Ytterligere $10 \%$ hadde klare tegn på sensitiv selvhenføring, og vel $5 \%$ var usikre. Prosenttallet for de pasienter som med sikkerhet ikke hadde vrangforestillinger, lå på under $10 \%$.

Det relativt høye tall på vrangforestillinger kom ikke helt uventet. Følelsen av å være forfulgt og/eller forurettet, danner et forholdsvis lett forståelig grunnlag for ,motaksjoner“ fra en pasients side. Dette vil ofte bringe ham/henne i konflikt med loven. 
Forstyrrelser av stemningsleiet er mindre velkjent $\mathbf{i}$ forbindelse med lovovertredelser hos psykiatriske pasienter. Det var derfor et noe uventet funn at over halvparten av de unders $\phi$ ktes stemningsleie var preget av dysfori og/eller depresjon. Det fremgikk imidlertid ikke av journalene om disse beskrevne stemningsforandringer var situasjonsbetingete, d.v.s. en f $\varnothing$ lge av pasientenes konflikt med loven, eller om de kunne sees på som mere utløsende i forhold til de begåtte lovovertredelser.

Vel $60 \%$ av de unders $\phi$ kte hadde ulike former for hallusinose, her som ellers dominerte de auditive med vel halvdelen av alle registrerte sansebedrag. Tegn på demens fantes i bare $1 / 3$ av pasientene. Den diagnostiske fordeling slik den fremgikk av sykehusenes journaler og de rettspsykiatriske erklæringer fremgår av tabell 5 .

Tabell 5. Psykiatriske diagnoser ved lovovertredelsen (i \%).

\begin{tabular}{|c|c|c|c|c|c|c|}
\hline & \multicolumn{2}{|c|}{ Menn } & \multicolumn{2}{|c|}{ Kvinner } & \multicolumn{2}{|c|}{ I alt } \\
\hline & $\mathrm{N}=156$ & $\%$ & $\mathrm{~N}=23$ & $\%$ & $\mathrm{~N}=179$ & $\%$ \\
\hline Schizofrene psykoser & & 38.5 & & 13.0 & & 35.2 \\
\hline Reaktive psykoser & & 23.1 & & 47.7 & & 26.3 \\
\hline Manisk-depressive psykoser & & 3.8 & & 13.0 & & 5.0 \\
\hline Senile og presenile psykoser & & 3.8 & & 4.3 & & 3.9 \\
\hline Psykoser ved oligofreni & & 7.7 & & - & & 6.7 \\
\hline $\begin{array}{l}\text { Epileptogene, posttraumatiske } \\
\text { andre organogene psykoser }\end{array}$ & $\operatorname{og}$ & 11.5 & & 4.3 & & 10.7 \\
\hline Andre psykoser (NOS) & & 11.5 & & 17.3 & & 12.3 \\
\hline
\end{tabular}

Det er i denne tabell ikke foretatt noen oppdeling i pasienter lagt inn for første gang og gjeninnlagte pasienter. Tallene ville antagelig bli for små. I den offisielle statistik for de år det gjelder, er det beskrevet til dels påtagelige forskjeller mellom disse to pasientkategorier. Dette gjelder ikke minst diagnosene schizofreni, schizofrene psykoser og manisk-depressive psykoser. Begge stilles nesten dobbelt så hyppig ved gjeninnleggelser enn ved f $\varnothing$ rste gangs innleggelse (schizofrene psykoser ca. $15 \%$ ved førstegangsinnleggelse og $30 \%$ ved gjeninnleggelse, maniskdepressive psykoser ca. $5 \%$ ved f $\varnothing$ rstegangsinnleggelse og $10 \%$ ved gjeninnleggelse). På den andre siden utgjør gruppen senile og presenile psykoser ca. $10 \%$ av alle f $\varnothing$ rstegangsinnleggelser, mot bare ca. $2 \%$ ved gjeninnleggelser. Det dreier seg jo om kroniske pasienter som sjelden blir utskrevet, henholdsvis gjeninnlagt. For alle disse diagnosenes vedkommende er det imidler- 
tid ingen påfallende forskjeller mellom våre unders $\phi$ kte pasienter på den ene siden og den psykotiske totalbefolkning på den annen. Derimot finner vi klare forskjeller når det gjelder psykoser ved oligofrenier. De utgjør i landsmålestokk ca. $2 \%$ av innleggelsene (både førstegangsinnlagte og gjeninnlagte), mens de i vårt materiale utgjør vel $6 \%$ av innleggelsene. Diagnosegruppen epileptogene, post-traumatiske og andre organogene psykoser viser et liknende forhold. I den psykotiske totalbefolkning utgj $\phi r$ de tilsammen mellom 2 og $3 \%$ ved både førstegangsinnleggelser og gjeninnleggelser, mens de i vårt materiale utgj $\phi \mathbf{r}$ ca. $10 \%$. Disse tall bekrefter de ovenfor antydede funn, at det i det aktuelle materiale finnes en ikke ubetydelig del av pasienter med organogene tilstander som gjør dem mer vulnerable og mindre motstandsdyktige.

Unders $\varnothing$ kelsen viser videre at det gjelder overveiende kroniske pasienter. Psykosen hadde $\mathrm{i}$ halvdelen av tilfellene vart $\mathrm{i} 3$ år eller mer, og i bare $15 \%$ kunne den anses som akutt (varighet mindre enn $6 \mathrm{mndr}$ ). Også lovovertredelsene var gjentakelser, idet ikke mindre enn $2 / 3$ hadde vart i kontakt med politiet flere ganger f $\phi r$ den aktuelle sak, og 1/4 hadde hatt én kontakt med politiet og fått henlagt saken på grunn av ,bevisets stilling“. Till tross for disse hyppige politikontakter, hadde bare noe over $1 / 4(28.5 \%)$ vært tiltalt og straffed $\varnothing \mathrm{mt}$.

Man får inntrykk av at påtalemyndighetene ikke har en tendens til å gripe altfor energisk inn overfor dette klientel. Dette støttes også av kjensgjerningen at bare 18 pasienter hadde vært observert judisielt tidligere, d.v.s. f $\varnothing \mathbf{r}$ 1965. Av disse var 7 (6 menn og 1 kvinne) blitt ansett som sinnssyke, mens de andre var blitt vurdert som lidende av varig svekkede sjelsevner. Bare hos den ene observerte kvinne anså de sakkyndige den gangen at det ikke forelå fare for gjentagelse av straffbare handlinger, en beskjeden optimisme som dog ikke holdt stikk. Alle tidligere observerte hadde hatt tilbakefall og var blitt psykotiske etter den f $\varnothing$ rste judisielle observasjon.

Mulig sammenheng mellom psykiatrisk lidelse og lovovertredelse

Det er som kjent uhyre vanskelig å påstå eller å benekte med sikkerhet en utvetydig kausalsammenheng mellom en lovovertredelse og en påvist psykotisk tilstand. Denne erfaring danner bl. a. grunnlaget for det såkalte medisinske prinsipp som er gjeldende i norsk lovgivning, og som betinger straffrihet for en gjerningsmann som har vært sinnssyk på gjerningstiden. Diskusjonen om berettigelsen av dette prinsipp eller om n $\phi$ dvendigheten av en særskilt bed $\varnothing$ mmelse av tilregneligheten ved siden av sinnssykediagnosen, skal ikke tas opp her. Uavhengig av de fremkomne reaksjoner, har man i det foreliggende materiale fors $\phi \mathrm{kt}$ 
å finne ut om og i hvilken utstrekning det var mulig og rimelig å etablere kausale relasjoner mellom psykosen og den registrerte lovovertredelse. Hos 30 pasienter (24 menn og 6 kvinner, eller $16.8 \%$ ) var det overveiende sannsynlig at den straffbare handling var en direkte følge av pasientens persekutorisk-paranoide holdning. Det gjaldt enten et forsvar mot formentlige forf $\phi$ lgere eller hevn for urett vedkommende mente å ha vært utsatt for. Hos 13 pasienter $(11+2$, eller $7.3 \%)$ var erotiske konflikter av paranoid natur grunnlaget for lovovertredelsen, og 2 pasienter (menn) hadde fått ,befalinger fra høyere vesener" om å begå den handling som hadde bragt dem i konflikt med samfunnet. Hos 3 pasienter (1 mann og 2 kvinner!) forelå det klare melankolske sykdomsbilder med ,utvidet“ suicid hvor offeret ikke overlevde, mens pasienten ikke hadde klart å gjennomf $\phi \mathrm{re}$ sitt fors $\phi \mathrm{k}$ fullstendig. Hos de resterende $3 / 4$ (73.2\%) kunne man ikke uten videre peke på en direkte motiverende kausal sammenheng mellom psykosen og handlingen.

Her var handlingene preget enten av lav impulskontroll eller kortslutningshandlinger, eller de var utløst av akutte provokasjoner som krangel o.l. Nedsatte motforestillinger på grunn av alkoholbruk er beskrevet i nesten halvdelen (eller $48.6 \%$ ) av tilfellene. Ingen av disse faktorer kan anses som spesifikke for psykotiske tilstander. I tillegg til de ovenfornevnte momenter, kunne man hos ca. $5 \%$ anta at tap av støttende kontakter og i $2 \%$ at tap av stilling og/eller direkte sosial n $\phi$ d var utl $\phi$ sende årsak til den begåtte lovovertredelsen. Endelig fremkom det hos noe mindre enn $10 \%$ at kroniske vansker $\mathrm{i}$ arbeidet og andre langsiktige belastninger hadde utløst den kriminelle handling. Men heller ikke her finner man noe spesifikt for psykotiske tilstander.

\section{Lovovertredelsenes art}

Lovovertredelsene ble inndelt i de vanlige 4 grupper: voldshandlinger, vinningsforbrytelser, sedelighetsforbrytelser og ,andre".

Voldsforbrytelser begått av sinnssyke personer har alltid tiltrukket seg publikums eksessive oppmerksomhet. I den foreliggende unders $\phi$ kelse har 66 personer, d.v.s. $37 \%$ av alle utf $\varnothing$ rt voldshandlinger, hvorav 48 mot andre personer. Dette er et relativt $\mathrm{h} \phi \mathrm{yt}$ tall, idet voldshandlingenes andel av den totale kriminalitet i Norge ligger jevnt under $10 \%$ (5). Hos våre pasienter dreide det seg i 7 tilfeller om drap, to av disse var dobbeldrap og i et tilfelle var det et drapsfors $\varnothing \mathrm{k}$ i tillegg til et gjennomf $\phi \mathbf{r t}$ drap. I ett tilfelle har drapsmannen tatt seg selv av dage etter å ha drept sin hustru, og $\mathrm{i}$ et annet har han fors $\varnothing \mathrm{kt}$ å drepe seg selv, men mislyktes. I de andre tilfeller dreier det seg om alvor- 
lige trusler, legemsfornærmelser og grov legemsbeskadigelse. De to kvinners voldshandlinger var bare rettet mot barn, mens mennenes voldshandlinger var mindre selektive. Voldshandlingenes psykosekorrelerthed viser seg også ved valg av ofre. Syv av ofrene var gift med gjerningsmannen, 3 hadde andre erotiske relasjoner til dem, og 15 andre var nære slektninger. I 7 andre tilfeller hadde offeret en rollespesifikk relasjon til gjerningsmannen, f. eks. lensmann, sosialsjef, distriktslege o.s.v.

Vinningsforbrytelser er begått av 49 personer (27\%). Tolv personer $(7 \%)$ har begått sedelighetsforbrytelser ikke kombinert med vold, og resten, d.v.s. 52 personer, henholdsvis $29 \%$, har begått lovovertredelser som ikke kommer under disse tre hovedgrupper. I de færreste av disse tilfellene kunne man påvise noen psykoserelasjoner. Man får således allerede ved en første noe mere detaljert vurdering inntrykk av at det er en viss forskjell mellom vinnings- og voldsforbrytelser når det gjelder spørsmålet om handlingen er overveiende psykotisk betinget eller ei.

\section{Den offentlige reaksjon}

Både politimyndighetenes og de medisinske myndigheters reaksjoner er vurdert. Fra politiets side ble 139 tilfeller ansett som avsluttet etter at de var blitt etterforsket og etter at det var blitt klarlagt at gjerningsmannen hadde vært sinnssyk på tiden for de påklagede handlinger. I 33 tilfeller ble det iverksatt judisiell observasjon, og i 23 tilfeller av disse forlangte politiet at sikringssak skulle bli reist, men dette tall $\phi$ kte etter statsadvokatenes inngripen til 30 pasienter som ble innlagt i psykiatrisk sykehus etter å ha vært $\mathrm{d} \varnothing \mathrm{mt}$ til sikring der. Sikringssaker reises hyppigst ved voldsforbrytelser, og relativt sjelden ved andre lovovertredelser. Ellers ble 113 pasienter innlagt i psykiatrisk sykehus på „vanlig måte“, d.v.s. etter $\S 5$ i Lov om psykisk helsevern.

I 19 tilfeller ble ingen reaksjonsform brukt, d.v.s. gjerningsmannen ble ikke innlagt, lovovertredelsen var blitt ansett som så bagatellmessig at sanksjoner fra påtalemyndighetens side kunne falle bort. Psykiatrisk ble pasientenes lidelse ansett som enten ikke behandlingskrevende eller tilgjengelig for ambulant behandling. De resterende 17 eller ca. $10 \%$, har befunnet seg i institusjonell psykiatrisk helsevern da de begikk sine lovovertredelser. Påtalemyndigheten fant ingen grumn til å gripe inn overfor dem. På institusjonene ble det i henhold til journalene nok tatt en del sanksjoner mot disse pasienter, de ble f. eks. flyttet til en annen avdeling, eller deres status ble forandret.

Disse tall viser bl. a. at de fleste psykotiske lovovertredere blir innlagt uten hensyntagen til de straffbare handlinger de har gjort seg skyldige i. Selv i disse tilfeller opptrer politiet bare i 
et fåtall ganger som tutor, d.v.s. den myndighet som forlanger pasienten tvangsinnlagt og behandlet. I de fleste tilfeller overtar familien det offisielle ansvar for sine pasienter. Politiet synes i betydelig grad å neglisjere de sinnssykes lovovertredelser. Denne fremgangsmåte vil for de fleste fortone seg som human. Men det har også vært reist motforestillinger mot at en formodet sinnssyk ikke får anledning til å få sin sak prøvet for retten. Det heter hos kritikerne at en slik person blir ,sperret inn“ på ubegrenset tid i et sinnssykehus uten lov og dom. Det gjennomgåtte materiale har ikke gitt grunnlag for slike bebreidelser eller bekymringer, men det sier seg selv at en grundig psykiatrisk bed $\phi$ mmelse er minst like viktig når det gjelder mulige sinnssykelovovertredere som ikke-lovovertredere.

Unders $\varnothing$ kelsen viser videre hevet over enhver tvil at dette også svarer til legenes oppfatning, slik den kommer til uttrykk i sykehusets journaler. Det vanlige er at legene enten ikke kjenner eller ikke synes å legge brett på de straffbare handlinger deres pasienter måtte ha begått $f \varnothing r$ innleggelsen. En registrering av pasienters lovovertredelser finnes ikke i det hele tatt. Gjennomgåelsen av sykehistoriene til alle de pasienter hvor det hadde vært åpnet politietterforskning og hvor saken var blitt henlagt, viser at bare de aller færreste inneholder en bemerkning om pasientens konflikt med loven. Man må derfor anta at svært mange psykiatriske pasienter er innlagt uten at deres lovovertredelser taes med i de anamnestiske opplysninger eller diagnostiske overveielser. Dette skulle st $\varnothing$ tte den oppfatning som Lagos et al. har gjort seg til talsmenn for.

\section{Korrelasjoner}

En har vært interessert i å finne frem om det er noen spesielle faktorer hos de unders $\varnothing$ kte som kan antas å være utslagsgivende for noen av de fremkomne resultater. Det er $58 \%$ av de unders $\varnothing$ kte som er vokst opp i et ikke-harmonisk barndomshjem. Hos relativt flere av dem er det beskrevet ,asosiale trekk" i barndommen, de har dårligere skolegang og deres intellektuelle nivå ligger gjennomsnittlig lavere enn $i$ den andre gruppen. Deres arbeidsliv betegnes hyppigere som ustabilt, og deres skilsmissehyppighet er dobbelt så h $\varnothing \mathrm{y}(14 \% \operatorname{mot} 7 \%)$ enn i gruppen hvor det ikke-harmoniske barnehjem ikke er presisert. De har vært hyppigere i kontakt med politiet, og deres psykotiske tilstand er blitt betegnet som kronisk i mange flere tilfeller enn i den andre gruppen. Deres forhold til alkohol er likeledes hyppigere avvikende. Å vokse opp i et barndomshjem som oppleves som uharmonisk er således en ekstrabelastning, også innenfor dette generelt underpriviligerte klientel. Det synes å f $\varnothing \mathrm{re}$ til at de som har hatt denne ekstra vanskelige utgangsposisjon blir til en „minusgruppe“ også blant kriminelle psykotikere. 
Også varigheten av skolegangen synes å ha en viss prognostisk betydning/være interkorrelert med en rekke faktorer. Det er ikke bare yrkesforhold som er bedre hos dem som har mer enn 7 års skolegang, men også deres arbeidsstabilitet er bedre, og deres misbruk av alkohol sjeldnere. Som gruppe har de psykiatrisk sett noen færre pasienter med paranoide symptomer enn gruppen med minimal skolegang.

De fleste positive korrelasjoner får man imidlertid i forhold til lovovertredelsenes art. Pasienter som er vokst opp i et hjem hvor forholdene blir karakterisert som ikke-harmoniske, og pasienter hvor det er beskrevet spesielt fremtredende eller avvikende trekk i barndommen, begår flest vinningsforbrytelser. Men ikke voldsforbrytelser. Dette vil st $\phi$ tte den ovenfornevnte formodning at voldsforbrytelser i større grad er situasjonsbetinget, og etter all sannsynlighet psykoseutløst. For denne oppfatning taler også det forhold at pasienter som har hatt et stabilt arbeidsforhold er underrepresentert både nâr det gjelder vinnings- og sedelighetsforbrytelser, men ikke når det gjelder voldsforbrytelser. Det er ikke urimelig å tenke seg at fortrengt aggressivitet plutselig kan få sin utløsning i form av situasjonsbetinget, psykosekorrelerte voldshandlinger.

Sedelighetsforbrytelser begås i større utstrekning av intellektuelt mindre bra utstyrte personer enn av ,intellektuelt normale“ (10\% mot $5 \%$ i den ikke subnormale gruppen). Dette forhold trer enda tydeligere frem ved den yrkesmessige fordeling. $\mathrm{Ni}$ av de 12 sedelighetsforbrytelser er begătt av de ikke-faglærte. Relativt flest sedelighetsforbrytelser er også begått av de 43 som aldri har hatt fast følge eller normal kontakt med det annet kjønn, nemlig halvparten av de 12 registrerte. De 67 ikke-gifte svarer for ytterligere 4, mens de 69 gifte, f $\varnothing$ rgifte og skilte tilsammen har begått $\mathrm{i}$ alt bare 2 sedelighetsforbrytelser. I denne forbindelse er det kanskje også verdt å nevne at kun en av dem som har utf $\varnothing$ rt sin militærtjeneste har begått en sedelighetsforbrytelse. Alle andre er begått av folk som er blitt kjent udyktige før eller under tjenesten.

Det synes også å være en klar sammenheng mellom lovovertredelsens art og den sosiale situasjon pasientene levde under på den tiden de straffbare handlinger ble begått. Forholdsvis færre vinningsforbrytelser begikk de pasienter som levde under relativt sosialt tilfredsstillende forhold, enten i ekteskap eller alene. Derimot begikk de pasienter relativt flest vinningsforbrytelser som levde under ekstremt lite tilfredsstillende sosiale forhold, eller som var i offentlige institusjoner, sykehus, pleiehjem o. s. v. På den andre siden begikk pasienter som bodde hos sine foreldre eller sammen med andre familiemedlemmer som de for det meste var avhengige av, flest sedelighetsforbrytelser. Igjen 
får man et meget tydelig inntrykk av at vinningsforbrytelser i forholdsvis beskjeden grad er psykoserelatert og mere avhengig av pasientens totale, sosiale situasjon og holdning.

Det har vært et noe uventet funn at alkoholmisbruk synes å være jevnt fordelt på alle lovovertredelsens arter.

Når det gjelder psykiatriske symptomer foreligger det en klar sammenheng mellom lovovertredelsenes art på den ene siden og vrangforestillinger, særlig forf $\phi$ lgelsesforestillinger på den annen. Pasienter med slike vrangforestillinger begår relativt færrest vinnings-, men flest voldsforbrytelser, mens forholdet er det motsatte uten påviste vrangforestillinger. Demenssyndromet derimot, forekommer hyppigst hos pasienter som begår sedelighetsforbrytelser. De 49 pasienter med dette syndrom er ansvarlige for like mange sedelighetsforbrytelser som de 130 pasienter uten det.

\section{Voldsforbrytelser overfor andre personer}

Det neste spørsmål vi фnsket å få besvart var om pasienten som har begått voldsforbrytelser overfor andre personer frembyr noen spesielle karakteristiske tegn: Det finnes 48 slike personer som er sammenlignet med de 131 som ikke har begått slike forbrytelser. Det er ingen markant forskjell i alderssammensetning, og det er av underordnet betydning om de er f $\varnothing \mathrm{dt}$ i eller utenfor ekteskap, om de er vokst opp i sosialt tilfredsstillende kår eller ikke, og om de interpersonelle forhold i barndomshjemmet kunne betegnes som harmoniske eller ikke. Også skolegang og intelligensnivået synes å være uten betydning.

Til å begynne med virket det noe forbausende og uventet at gruppen som hadde begått relativt flest voldsforbrytelser sto best når det gjaldt en rekke premorbide faktorer. Personlighetsbeskrivelsen som er brukt i sykehusets journaler viser at de som er blitt betegnet som „,upåfallende“ har begått relativt flest voldsforbrytelser, mens de som er blitt betegnet å ha hatt asosiale trekk i barndommen, figurerer lavest i denne gruppen. Liknende, tilsynelatende uventede forhold får man når det gjelder pasientenes arbeids- og yrkesforhold. Av de 91 som er betegnet som stabile arbeidere, har 34 begått voldshandlinger, mens av de 88 bare 14. Av de 55 faglærte arbeidere/funksjonærer, er det ikke mindre enn 20 som har begått voldshandlinger, mens av de 111 ikke-faglæerte arbeidere var det bare 22. Heller ikke når det gjelder pasientenes sivilstand får man det bildet man er vant til når det gjelder psykotiske pasienter, at de gifte er de ,,hest beskyttede“, minst psykotiske o. s. v. I vårt materiale er det de gifte som leder antall voldshandlinger mot andre personer, idet hele 21 av de 47 gifte og førgifte har begått voldshandlinger, mens det er bare 3 av de 20 skilte som har begått slike 
handlinger. I samsvar med dette er det også funnet at de pasienter som angis å ha levd under sosialt relativt tilfredsstillende forhold, er de som har forholdsvis flest voldsforbrytelser. Avhengighet/misbruk av alkohol synes derimot ikke å spille noen rolle i den aktuelle forbindelse.

Psykiatrisk sett har de pasienter som ikke har paranoide forestillinger færrest voldshandlinger, men ellers er voldshandlinger jevnt fordelt på alle psykiatriske diagnoser. Det samme gjelder også om pasientene tidligere har vært i psykiatrisk behandling, i kontakt med politiet, judisielt observert, og om psykosen har vært ansett som kronisk eller akutt.

Med alle forbehold som materialets små tall gjør påkrevet, og med de muligheter for ikke helt nøyaktige opplysninger som man må regne med ved en slik unders $\phi k e l s e$, fremtrer de pasienter som har begått voldshandlinger her som en nærmest „positiv“ gruppe med en mindre belastet premorbid personlighet, forholdsvis god yrkesmessig utdannelse og stabilitet, bra sivil status m. m. Det er derfor nærliggende å anta at en langvarig fortrengt aggressjon, det være seg i arbeidslivet eller i ekteskapet, muligens har funnet sitt akutte utl $\phi$ i en psykotisk voldshandling. Disse lovovertredelsenes situasjonsbetingete karakter og psykoseavhengighet synes derfor temmelig sannsynlig.

\section{Etterunders $\phi$ kelse}

Ved etterunders $\varnothing$ kelsen som ble foretatt utelukkende på grunnlag av de opplysninger man fant ved gjennomgåelse av de foreliggende dokumenter, det være seg $\mathrm{i}$ sykehusenes journaler, i politiaktene, strafferegisteret og $\mathrm{i}$ Statistisk Sentralbyrås fortegnelser over avd $\varnothing$ de, kunne man registrere den videre skjebnen til over $90 \%$, eller 153, av de opprinnelig unders $\varnothing$ kte 179 personer. Færrest opplysninger fikk man naturlig nok om de pasienter hvor lovovertredelsen var blitt ansett som minimal, og som ikke var blitt innlagt i noen psykiatrisk institusjon. Det synes som om vurderingen på tiden for de påklagede handlinger var preget av særdeles godt skjønn, idet de nesten alle ,forsvant ut av aktene“. Det offentlige, det være seg politiet, påtalemyndigheter, rettsapparatet eller det psykiske helsevern, hadde ingen ytterligere befatning med dem under den 7-12 år lange observasjonstid.

Nesten $2 / 3$ (105) av dem hvis skjebne man kunne følge, var fortsatt under institusjonell psykisk helsevern, 81 i psykiatriske sykehus, de andre i sykehjem, henholdsvis familiepleie. Elleve var under psykiatrisk ettervern, mens 16 måtte anses som helbredet, uten mén, og sosialt veltilpasset. Hele 21 var døde i. observasjonstiden, hvorav ikke mindre enn 5 ved suicid. 
Av de sykehusinnlagte var bare 3 menn under fortsatt (fornyet) sikring på Reitgjerdet sykehus (sykehus for særlig vanskelige og kriminelle sinnslidende). De var alle 3 blitt $\mathrm{d} \phi \mathrm{mt}$ gjentatte ganger for recidiverende vinningsforbrytelser, og alle 3 hørte til den gruppen med en utdannelse som ligger under det vanlige norske minimum.

Klinisk sett bekrefter disse tall fra etterunders $\varnothing$ kelsen det inntrykk man hadde ved unders $\varnothing$ kelsens begynnelse, nemlig at det dreier seg om et kronisk klientel med beskjeden tendens til fullstendig helbredelse og sosial tilpasning.

Sett på denne bakgrunn, er den registrerte tilbakefalls-kriminalitet forholdsvis beskjeden. Bare 46 personer (41 menn og 5 kvinner), d. v. s. knapt $1 / 4$ av de opprinnelig 179 unders $\phi$ kte pasienter, er innført igjen i strafferegisteret etter den 31.12.1967, d. v. s. dagen da selve unders $\phi$ kelsesperioden var avsluttet og observasjonstiden begynte. Beregnet for de ulike arter av lovovertredelser, har $1 / 3(32 \%)$ av voldsforbryterne recidivert, mot $1 / 4(26 \%)$ vinningsforbrytere, og bare $16 \%$ sedelighetsforbrytere.

Med andre ord er av de 179 unders $\phi$ kte, 133 (eller $74.3 \%$ ) ikke blitt registrert som recidivister. For en realistisk bed $\varnothing \mathrm{m}-$ melse av dette tall, må man bl. a. ha in mente at de fleste av dem tilbragte mange år i lukkede institusjoner, noe som nok må antas å ha redusert faren for recidiv. Likevel var det interessant å unders $\varnothing$ ke om recidivistene frembød noen spesifikke karakteristika, og i tilfelle hvilke: De som er f $\phi \mathrm{dt}$ utenfor ekteskap har recidiver i $39 \%$, mot $24 \%$ for dem som er f $\varnothing \mathrm{dt}$ i ekteskap, videre har unders $\varnothing$ kte med skolegang inntil 7 år $52 \%$ recidiver, mot $18 \%$ hos dem med langvarigere utdannelse. Intelligensmessig subnormalt utstyrte recidiverer i $40 \%$, mot $21 \%$ hos de normalt utstyrte. Også de ikke-faglærte recidiverer hyppigere enn de faglærte (33\% mot $13 \%)$. Det samme gjelder for de ikke stabile i arbeidslivet $(65 \% \operatorname{mot} 15 \%)$. Som ventet slår alkoholbruk/misbruk tydelig ut når det gjelder recidivene, $16 \%$ for avholdende/moderate mot $35 \%$ hos misbrukerne.

Psykiatrisk var det verdt å merke seg at fravær av paranoide forestillinger gir noe flere recidiver $(34 \%)$, mens persekutoriske idéer ligger på gjennomsnittet. Det er nærliggende å anta at klart psykotisk betingete lovovertredelser f $\varnothing$ rer til adekvat psykiatrisk behandling, og dermed til en reduksjon av recidivfaren. Dette viser seg også hos personer med demenssyndromet (recidiv $15 \%$ ), selv om "behandlingen“ her hovedsakelig ligger i hospitaliseringen.

Tidligere kontakt med politiet synes å være et „pålitelig tegn“ på recidivfare. De pasienter som aldri hadde vært i kontakt med politiet recidiverer i bare $7 \%$, mens de som har vært straffet flere ganger i $43 \%$. 
Voldsforbrytelser som er begått mot nære slektninger viser en lavere recidivfrekvens $(14 \%)$ enn andre voldsforbrytelser. Recidivfrekvensen er endelig høyest (nesten $50 \%$ ) hos dem hvor sikringssaker har vært reist eller også bare foreslått av påtalemyndighetene.

\section{Avsluttende bemerkninger}

Det foreliggende materialet som består av 179 psykotiske lovovertredere, som i en 3-års periode ble innlagt i psykiatriske sykehus i Norge, er for lite til å trekke generelle eller vidtgående konklusjoner av. Med alle n $\varnothing$ dvendige forbehold, kan det dog pekes på at kriminaliteten ikke synes å være høyere blant den psykotiske befolkning enn blant befolkningen generelt. Klientelet synes å være en særdeles underpriviligert befolkningsgruppe når det gjelder sosiale og interpersonelle oppvekstkår. Dessuten inneholder den en betydelig andel av hjerneorganisk skadete personer. Også utdannelses- og yrkesfordelingen er karakteristisk for en sterkt underpriviligert befolkningsgruppe med sviktende sosial og heteroseksuell tilpasning.

Psykiatrisk er det en forholdsvis kronisk populasjonsgruppe med en diagnostisk fordeling hvor psykoser hos oligofrene og hjerneorganikere forekommer betydelig hyppigere enn i gjennomsnittsbefolkningen.

Når det gjelder lovovertredelsens art er det voldsforbrytelser som dominerer i dette materialet, i motsetning til hva tilfellet er i den generelle kriminalitet.

Den offentlige reaksjon synes å være forholdsvis lempelig overfor lovovertredere som blir funnet å være psykotiske, idet de fleste blir innlagt uten hensyntagen til de straffbare handlinger de har gjort seg skyldige i. Dette gjelder imidlertid ikke voldsforbrytelser.

Det synes å være en tydelig forskjell i personlighetsprofilene mellom psykotikere som begår vinningsforbrytelser og slike som begår voldsforbrytelser, særlig overfor andre personer. Vinningsforbrytere har dårligere sosial bakgrunn, dårligere skole- og yrkesutdannelse, labile arbeidsforhold, mens det motsatte er tilfelle for voldsforbrytere.

Hovedinntrykket er at det foreligger to hovedgrupper av forbrytelser hos våre unders $\varnothing$ kte pasienter. På den ene siden sterkt psykoserelaterte situasjonsbetingete handlinger. Blant disse dominerer voldshandlinger av paranoide pasienter, særlig mot slektninger, og disse gir sjelden tilbakefall. På den andre siden har vi de ,vanlige“ småkriminelle handlinger, særlig representert av vinningsforbrytelser, som synes å forekomme blant en psykotisk populasjon i mer eller mindre like h $\phi y$ grad som i en tilsvarende underpriviligert populasjon, og denne kriminalitet 
kan antas å være uavhengig av vedkommendes psykotiske tilstand.

Det ville være av betydning om liknende undersøkelser med større materiale kunne foretas for å bekrefte eller avkrefte delte inntrykk. En slik unders $\phi$ kelse vil i alle fall være påkrevet dersom de skulle danne grunnlag for lovmessige forandringer overfor psykotiske pasienter og spørsmålet om tilregnelighet. I alle fall synes unders $\phi$ kelsen å bekrefte den oppfatning som Gunn har gitt uttrykk for, at korrelasjonen mellom psykoser og lovovertredelser er et meget mangfoldig og komplisert problem, som fortjener å bli studert videre.

\section{Eitinger}

\section{LITTERATUR}

1 Böker, W. \& H. Häfner: Gewalttaten Geistesgestörten. Springer, Berlin, Heidelberg, New York, 1973.

2 Giovannoni, J. M. \& L. Gurel: Socially disruptive behaviour of exmental patients. Arch. Gen. Psychiatr. 1967: 17: 146-153.

3 Gunn, J.: Criminal Behaviour and Mental Disorder. Brit. J. Psychiatr. 1977: 130: 317-329.

4 Guze, S. B.: Criminality and Psychiatric Disorders. Oxford University Press, New York, 1976.

5 Hauge, R.: Vold og voldskriminalitet. Forskningsnytt 1974: 19: $10-14$.

6 Häfner, H. \& W. Böker: Mentally disordered violent offenders. Soc. Psychiat. 1973: 8: 220-229.

7 Lagos, J. M., K. Perlmutter \& H. Saexinger: Fear of mentally ill: Empirical support for the common man's response. Am. J. Psychiatr. 1977: 134: 1134-1137.

8 Rappeport, J. R., G. Lassen \& N. B. Hay: A review of the literature on the dangerousness of the mentally ill. In: The Clinical Evaluation of the Dangerousness of the Mentally Ill. Ed. by Rappeport, J. R., Springfield (Ill.) Charles C. Thomas, 1967. (pp. 72-80).

9 Røstad, H.: Noen betraktninger om kriminalstatistikk og om kriminalitetsutvikling i Norge gjennom de siste 20 år. Nord. Tidsskr. Kriminalvidenskab, 1974.

10 Zitrin, A. et al.: Crime and violence among mental patients. Am. J. Psychiatr. 1976: 133: 142-149. 